ARQGA / 939

\title{
MALIGNANCY RISK PREDICTION FOR PRIMARY JEJUNUM-ILEAL TUMORS
}

\author{
Ruy Garcia MARQUES* and Margareth Crisóstomo PORTELA**
}

ABSTRACT - This work is aimed at identifying factors associated with primary jejunum-ileal tumors malignancy, defining a prediction model with sensitivity, specificity and accuracy to distinguish malign from benign neoplasms. These tumors are rare, have highly unspecific presentation and, frequently, are diagnosed late. We reviewed the charts of 42 patients with primary jejunum-ileal tumors treated in the Department of General Surgery of Rio de Janeiro State University Hospital, Rio de Janeiro, RJ, Brazil, from 1969 to 1998 . We performed bivariate analyses, based on $\chi^{2}$ test, searching associations between tumors malignancy and demographic and clinical variables. Then logistic regression was employed to consider the independent effect of variables previously identified on malignancy risk. The malign tumors included 11 adenocarcinomas, 7 leiomyosarcomas, 5 carcinoids and 4 lymphomas; the benign tumors included 10 leiomyomas, 2 hamartomas, and single cases of adenoma, multiple neurilemoma and choristoma. The bivariate analyses indicated the association between malignancy and palpable abdominal mass $(P=0.003)$, period from signs and symptoms onset to diagnosis $(P=0.016)$, anemia $(P=0.020)$, anorexia $(P=0.003)$, abdominal pain $(P=0.031)$, weight loss $(P=0.001)$, nausea and vomit $(P=0.094)$, and intestinal obstruction $(P=0.066)$; no association with patients demographic characteristics were found. In the final logistic regression model, weight loss, anemia and intestinal obstruction were statistically associated with the dependent variable of interest. Based only on three variables - weight loss, anemia and intestinal obstruction-the model defined was able to predict primary jejunum-ileal tumors malignancy with sensitivity of $85.2 \%$, specificity of $80.0 \%$, and accuracy of $83.3 \%$.

HEADINGS - Jejunal neoplasms. Ileal neoplasms. Risk factors.

\section{INTRODUCTION}

The jejunum-ileal segment accounts for $70-80 \%$ and $80-90 \%$ of the gastrointestinal tract length and surface area, respectively. Primary small bowel neoplasms constitute $1-5 \%$ of all tumors and less than $2 \%$ of the malign lesions located at the digestive tube, with a population incidence of
$1.6 / 100,000^{(2,10)}$. Concerning the relative rarity of small bowel tumors, compared with esophagus, stomach and colon tumors, many possible explanations have been speculated: (1) fluid content; (2) rapid intestinal transit; (3) alkaline $\mathrm{pH}$; (4) lower bacterial population than in colon and difference in bacterial metabolism; (5) high concentration of immunoglobulin A, particularly in the ileum; (6) possible cytogenetic

Department of General Surgery, Rio de Janeiro State University, Rio de Janeiro, RJ, Brazil.

** Department of Health Planning and Administration, National School of Public Health, Oswaldo Cruz Foundation, Rio de Janeiro, RJ, Brazil.

Address for correspondence: Dr. Ruy Garcia Marques - Rua Clóvis Salgado, 280 - apto. 104 - Recreio - 22795-230 - Rio de Janeiro, RJ, Brasil. e-mail: rmarques@uerj.br 
factors; (7) rapid proliferation and replacement of mucosa; and (8) stem-cells with more efficient apoptosis than in colon for removal of genetically modified cells $\mathrm{s}^{(1,4,7,14,16)}$.

Taking into account that the onset of a small bowel tumor may be associated with some degree of immunodeficiency, these patients would be more likely to present a second primary tumor. This really occurs in $17-20 \%$ of the cases, while the frequency of multiple primary tumors among patients with other types of cancer varies from $3-6 \%{ }^{(3,7)}$.

Jejunum-ileal tumors are generally only suspected under extreme circumstances such as the presence of palpable abdominal mass, intestinal obstruction, digestive hemorrhage or intestinal perforation. Due to their rarity and unspecific signs and symptoms, diagnosis is often late, what makes cure chances lower in the case of malign neoplasms, leading treatment to produce merely palliative effects. The prediction of tumor malignancy before surgery enable us to design more adequate therapeutic strategies for these patients.

This work evaluated the primary jejunum-ileal tumors casuistic of the Department of General Surgery of Rio de Janeiro State University Hospital. Moreover, it is aimed at identifying factors associated with the malignancy of these lesions, establishing a predictive model able to distinguish malign from benign neoplasias with expressive accuracy, sensitivity and specificity.

\section{METHODS}

\section{Casuistic}

We reviewed the charts of 42 patients with primary jejunum-ileal tumors operated in the Department of General Surgery of Rio de Janeiro State University Hospital, Rio de Janeiro, RJ, Brazil, from 1969 to 1998.

Among these patients, 27 had malign and 15 benign tumors. The malign tumors included 11 adenocarcinomas, 7 leiomyosarcomas, 5 carcinoids and 4 lymphomas; the benign, 10 leiomyomas, 2 hamartomas, and single cases of adenoma, multiple neurilemoma and choristoma.

The patients age varied between 2 and 88 years (mean of $52.6 \pm$ 22.0) and between 10 months and 78 years (mean of $49.9 \pm 21.7$ ), for patients with malign and benign tumors, respectively. Half of the patients were males, despite the predominance of females among those with malign neoplasms. Only eight patients (19.0\%) looked for medical care up to 30 days after the onset of symptomatology and 17 (40.5\%) between 1-6 months. Seven tumors (16.7\%) were found incidentally in patients without significant complaints, with surgery indications motivated by other diseases: four leiomyomas, two carcinoids and one hamartoma.

The most frequent symptom was abdominal pain (83.3\%), which was present in all symptomatic patients, followed by anemia $(61.9 \%)$ and nausea/vomit (54.8\%); weight loss, anorexia and palpable abdo- minal mass were found almost exclusively with malign tumors. Constipation and diarrhea were observed, respectively in $23.8 \%$ and $14.3 \%$ of the patients; low digestive hemorrhage (28.6\%) occurred only with melena, having no cases of hematemesis. Tumors close to Treitz ligament were responsible for complaints of post-prandial plenitude in six patients $(14.3 \%)$; fever occurred in three patients - two with intestinal perforations blocked with epiplo (leiomyoma and neurilemoma), and one leiomyosarcoma with a large tumoral necrosis area.

Twenty-four patients were operated electively, and other 18 under an urgency regimen. Among those submitted to elective surgery, the main diagnostic method employed was small bowel contrasted radiological exam, while for urgent cases, the only available exams were abdominal simple radiography and ultrasonography. Correct pre-surgical diagnoses were made for 13 (30.9\%) patients, being the small bowel contrasted radiological exam, individually or associated with other exams, important for nine of them.

Thirteen patients presented diagnosis of intestinal obstruction. Among them, 11 were related to malign tumors (three adenocarcinomas, three lymphomas, three carcinoids and two leiomyosarcomas), and two to benign (one leiomyoma and one choristoma).

Moreover, we should underline that there were no cases of celiac disease, Crohn's disease, neither any type of immunodeficiency, among the patients in this casuistic.

\section{STATISTICAL METHODS}

We performed bivariate analyses based on $\chi^{2}$-test in order to identify associations between the tumoral type (malign versus benign) and demographic (age and sex) and clinical variables. These, specifically, were expressed in terms of categorical variables indicating the tumor site (jejunum vs. ileum), the surgery type (elective vs. urgency), the symptomatology period prior to diagnosis, the presence (vs. absence) of intestinal obstruction, as well as the presence (vs. absence) of signs and symptoms such as palpable abdominal mass, digestive hemorrhage, intestinal rhythm alteration, anemia, anorexia, weight loss, abdominal pain and nausea/vomit.

We also employed regression logistic modeling to consider the independent effect of variables previously identified on jejunum-ileal tumors malignancy risk ${ }^{(6)}$.

The analyses were performed with the statistical package $\mathrm{SAS}^{(12)}$.

\section{RESULTS}

Table 1 presents the results of contingency tables relating the variable designating the tumoral type (malign vs. benign) to demographic and clinical variables.

There is no evidence in the sense of rejecting the null hypotheses of no associations between type and the demographic variables con- 
TABLE 1 - Bivariate analyses relating malign and benign primary jejunum-ileal tumors with clinical and demographic variables

\begin{tabular}{|c|c|c|c|c|c|c|}
\hline \multirow[t]{2}{*}{ Variable } & \multicolumn{2}{|c|}{ Malign } & \multicolumn{2}{|c|}{ Benign } & \multirow[t]{2}{*}{$\chi^{2}$} & \multirow[t]{2}{*}{ Prob } \\
\hline & $\mathrm{n}$ & $\%$ & $\mathrm{n}$ & $\%$ & & \\
\hline Age (years) & & & & & 0.104 & 0.7747 \\
\hline $0-49$ & 13 & 48.2 & 8 & 53.3 & & \\
\hline$\geq 50$ & 14 & 51.8 & 7 & 46.7 & & \\
\hline Sex & & & & & 2.593 & 0.107 \\
\hline Male & 11 & 40.7 & 10 & 66.7 & & \\
\hline Female & 16 & 59.3 & 5 & 33.3 & & \\
\hline Palpable abdominal mass & & & & & 8.575 & 0.003 \\
\hline Presence & 14 & 51.9 & 1 & 6.7 & & \\
\hline Absence & 13 & 48.1 & 14 & 93.3 & & \\
\hline Digestive hemorrage & & & & & 2.052 & 0.152 \\
\hline Presence & 17 & 63.0 & 6 & 40.0 & & \\
\hline Absence & 10 & 37.0 & 9 & 60.0 & & \\
\hline Local & & & & & 0.201 & 0.654 \\
\hline Jejunum & 18 & 66.7 & 11 & 73.3 & & \\
\hline Ileum & 9 & 33.3 & 4 & 26.7 & & \\
\hline Surgery & & & & & 0.864 & 0.353 \\
\hline Elective & 14 & 51.8 & 10 & 66.7 & & \\
\hline Urgent & 13 & 48.2 & 5 & 33.3 & & \\
\hline Intestinal rhythm alteration & & & & & 0.543 & 0.461 \\
\hline Presence & 14 & 51.8 & 6 & 40,0 & & \\
\hline Absence & 13 & 48.2 & 9 & 60.0 & & \\
\hline Symptomatology & & & & & 10.368 & 0.016 \\
\hline 0-30 days & 3 & 11.1 & 5 & 33.3 & & \\
\hline $1-6$ months & 13 & 48.2 & 4 & 26.7 & & \\
\hline $7-12$ months & 9 & 33.3 & 1 & 6.7 & & \\
\hline Incidental findings & 2 & 7.4 & 5 & 33.3 & & \\
\hline Anemia & & & & & 5.401 & 0.020 \\
\hline Presence & 19 & 70.4 & 5 & 33.3 & & \\
\hline Absence & 8 & 29.6 & 10 & 66.7 & & \\
\hline Anorexia & & & & & 8.575 & 0.003 \\
\hline Presence & 14 & 51.9 & 1 & 6.7 & & \\
\hline Absence & 13 & 48.1 & 14 & 93.3 & & \\
\hline Abdominal pain & & & & & 4.667 & 0.031 \\
\hline Presence & 25 & 92.6 & 10 & 66.7 & & \\
\hline Absence & 2 & 7.4 & 5 & 33.3 & & \\
\hline Loss of weight & & & & & 14.263 & 0.001 \\
\hline Presence & 20 & 74.1 & 2 & 13.3 & & \\
\hline Absence & 7 & 25.9 & 13 & 86.7 & & \\
\hline Nausea and vomit & & & & & 2.800 & 0.094 \\
\hline Presence & 18 & 66.7 & 6 & 40.0 & & \\
\hline Absence & 9 & 33.3 & 9 & 60.0 & & \\
\hline Intestinal obstruction & & & & & 3.389 & 0.066 \\
\hline Presence & 11 & 40.7 & 2 & 13.3 & & \\
\hline Absence & 16 & 59.3 & 13 & 86.7 & & \\
\hline
\end{tabular}


sidered (age and sex). Even in the case of the variable sex, for which the relative distribution of males and females seems to be different for patients with malign and benign tumors, suggesting higher risk of malignancy for females, the $\chi^{2}$-test is not statistically significant.

There is no association between tumoral type and tumor site, surgery type, digestive hemorrhage and intestinal rhythm alteration.

On the other hand, results indicate strong association between malignancy and the presence of palpable abdominal mass, anemia, anorexia, abdominal pain and weight loss, as well as symptomatology period prior to diagnosis.

Observed in $37.5 \%$ of all patients, the presence of palpable abdominal mass characterized $51.9 \%$ of malign tumor cases and only $6.7 \%$ of benign cases.

Concerning the period since first symptoms to diagnosis, we underline the predominance of incidental findings and the presence of symptoms for less than 30 days in the benign tumor group, against greater symptomatology periods in the malign tumor group.

The presence of anemia was registered in $70.4 \%$ of the patients with malign tumors and $33.3 \%$ of those with benign tumors. Anorexia and weight loss also occurred in the majority of patients with malign tumors $-51.9 \%$ and $74.1 \%$, being less frequent among those with benign tumors $-6.7 \%$ and $13.3 \%$, respectively.

Finally, results do not provide evidence at the $5 \%$, but do so at the $10 \%$ level of significance, in the sense of rejecting the individual hypotheses of no association of nausea/vomit and intestinal obstruction with tumor malignancy (vs. benignity). In both cases, the probability of occurrence seems to be higher for patients with malign tumors.

Table 2 shows the results of the final logistic regression model for prediction of jejunum-ileal tumors malignancy risk. This model was obtained from consideration of diverse signs and symptoms that were statistically associated with the event of interest, up to $10 \%$ level of significance, in the bivariate analyses.

Only weight loss, anemia and intestinal obstruction kept independent effects on the malignancy risk when clinical variables were controlled simultaneously. The odds of tumors being malign (instead of benign) among patients with weight loss were approximately 32 times as much as the odds among patients without weight loss. The odds ratio of malignancy (vs. benignity) considering patients with and without anemia, was 6.8. Finally, the odds of tumors being malign (vs. benign) for patients with intestinal obstruction were 8.3 times as much as those related to patients without intestinal obstruction.

In Table 2, we still should stress the following aspects: (1) the large confidence intervals defined for the odds ratios, maybe reflecting the small size of the sample studied; (2) the borderline statistical significance of anemia and intestinal obstruction; and (3) the model

TABLE 2 - Logistic regression model explaining the risk of primary jejunum-ileal tmors being malign

\begin{tabular}{lcccc}
\hline Variable & Coefficient estimate & Standard error & Pr $>\boldsymbol{\chi}^{2}$ & Odds ratio \\
\hline Intercept & -2.456 & 0.983 & 0.013 \\
Weight loss & 3.461 & 1.081 & 0.001 & 31.853 \\
Anemia & 1.920 & 0.992 & 0.053 & 6.822 \\
Intestinal obstruction & 2.119 & 1.117 & 0.058 & 8.320 \\
\hline
\end{tabular}

Log-likehood ratio $=24.864$ with 3 degrees of freedom $(P=0.0001)$

Concordant $=88.4 \%$; Discordant $=5.4 \%$; Tied $=6.2 \%$

TABLE 3 - Predicted probabilities of malignancy for different combinations of explanatory variable values

\begin{tabular}{|c|c|c|c|c|c|}
\hline Weight loss & Anemia & Intestinal obstruction & Benign & Malign & (MALIGN) \\
\hline 0 & 0 & 0 & 7 & 1 & 0.0790 \\
\hline 0 & 1 & 0 & 4 & 2 & 0.3693 \\
\hline 0 & 0 & 1 & 1 & 1 & 0.4166 \\
\hline 1 & 0 & 0 & 2 & 3 & 0.7322 \\
\hline 0 & 1 & 1 & 1 & 3 & 0.8297 \\
\hline 1 & 1 & 0 & 0 & 10 & 0.9491 \\
\hline 1 & 0 & 1 & 0 & 3 & 0.9579 \\
\hline 1 & 1 & 1 & 0 & 4 & 0.9936 \\
\hline
\end{tabular}

For a probability cut-off of 0.5 : sensitivity $=85.2 \%$; specificity $=80.0 \%$ 
fitness statistics, indicating a concordance of $88.4 \%$ between observed and predict values of the dependent variable.

It is also important to underline that the validity of modeling data related to jejunum and ileal tumors separately was compromised by the sample size. Controlling for tumor location in addition to weight loss, anemia and intestinal obstruction, however, leads intestinal obstruction to lose statistical significance, without adding significantly to model fitness. Intestinal obstruction is more likely to occur among those patients with ileal tumors, what may explain this result.

Table 3 presents the different possible combinations of the three explanatory variable values, and, in each case, the number of benign and malign tumors observed, as well as the probability of tumors malignancy according to the logistic regression model. This probability varies from $7.9 \%$ and $99.4 \%$ for patients with none or all considered clinical characteristics, respectively.

Figure 1 shows the sensitivity and specificity of the model obtained, considering various cut-off probabilities for discrimination of benign from malign tumors. Between the probabilities 0.58 and 0.68 , approximately, it is indicated a sensitivity of $85.2 \%$ and a specificity of $80.0 \%$.

\section{DISCUSSION}

Primary jejunum-ileal tumors are among the rarest tumors in the digestive tube, but they should always be in mind, mainly for those patients older than 40 years with unexplained recurrent abdominal

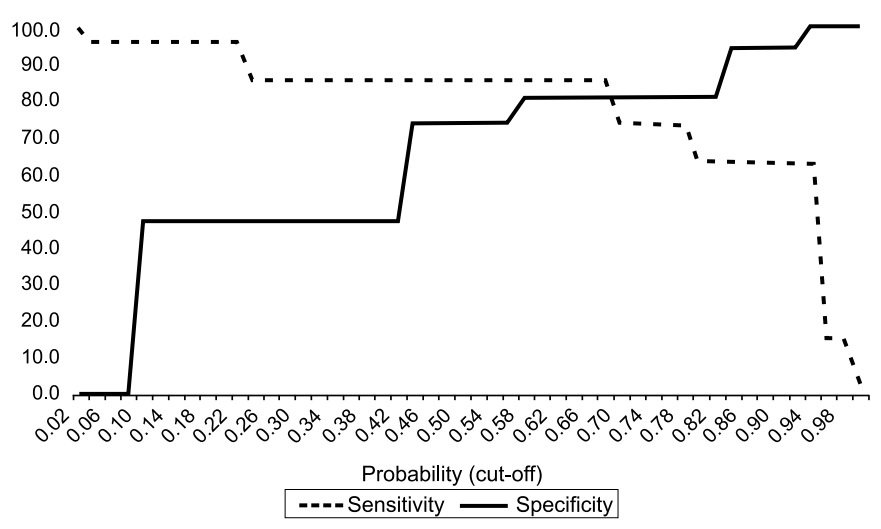

FIGURE 1 - Sensitivity and specificity of primary jejunum-ileal malignancy risk predictive model pain, obstructive intestinal symptoms, as well as anemia and gastrointestinal hemorrhage ${ }^{(9)}$.

Only when we make an early diagnosis we are able to provide a better prognosis to these patients. MAGLINTE et al. ${ }^{(8)}$ claim that the time lost before definitive diagnosis is due more to imprecise request of complementary exams, because of incorrect evaluation of clinical characteristics, than to delay of patients in looking for medical care. We had 13 pre-surgical diagnoses, which is in accordance to different authors that indicate percentages varying between 21 to $70 \%{ }^{(11,13)}$.

Malign tumors often produce more exuberant clinical manifestations than benign tumors. However, because of the unspecific signals and symptoms observed, the mean time required for diagnosis was close to 6 months, a fact that is corroborated by the literature ${ }^{(8,9)}$. Lesions that lead to digestive hemorrhage occur more frequently in the proximal small bowel segment, what is likely to be explained by the larger diameter of jejunum, allowing for tumoral growth with posterior ulceration and hemorrhage. Distal lesions obstruct the ileal lumen before the occurrence of such alterations.

In accordance to other authors, abdominal pain, weight loss, anemia and nausea/vomit represented the signals and symptoms more commonly observed in our patients with malign tumors ${ }^{(9,10,11)}$. Among these patients, $51.9 \%$ had palpable abdominal mass. Additionally, in a group of $13(30.9 \%)$ patients with intestinal obstruction, 11 were associated with malign tumors, confirming the delay in diagnosing these lesions. These findings conducted mostly to a purely palliative treatment.

This study takes into account statistical techniques largely applied in the medical field to identify demographic factors, signals and symptoms, as well as diagnosis data predictive of clinical outcomes ${ }^{(5,15)}$.

The proposition of a model involving only three variables weight loss, anemia and intestinal obstruction - makes possible the risk prediction for primary jejunum-ileal tumors with high sensitivity $(85.2 \%)$, specificity $(80.0 \%)$ and accuracy $(83.3 \%)$. Its implications include an earlier diagnosis and a better therapeutic planning for these patients.

The casuistic here considered embodies only 42 patients treated in the Department of General Surgery of the Rio de Janeiro State University Hospital. Even being clinical situations frequently generalizable, we underline the importance of validating our results in other settings, with larger samples. 
Marques RG, Portela MC. Predição do risco de malignidade em tumores jejuno-ileais primários. Arq Gastroenterol 2000;37(3):174-179.

RESUMO - O objetivo deste trabalho é identificar fatores associados à malignidade de tumores jejuno-ileais primátrios - tumores raros, com quadro clínico inespecífico e com diagnóstico freqüentemente tardio-estabelecendo um modelo de predição capaz de distinguir neoplasias malignas de benignas com acurácia, sensibilidade e especificidade expressivas. Foram revistos os prontuários de 42 pacientes com diagnóstico de tumor jejuno-ileal primário (27 malignos e 15 benignos) operados no Serviço de Cirurgia Geral do Hospital Universitário Pedro Ernesto da Universidade do Estado do Rio de Janeiro, Rio de Janeioro, RJ, entre 1969 e 1998. Realizaram-se análises bivariadas, com base no teste- $\chi^{2}$, buscando associações entre malignidade (vs benignidade) desses tumores com variáveis demográficas e clínicas. Regressão logística foi, então, utilizada para a consideração do efeito independente de variáveis previamente identificadas sobre o risco de malignidade. Os tumores malignos compreenderam 11 adenocarcinomas, 7 leiomiossarcomas, 5 carcinóides e 4 linfomas; os benignos, 10 leiomiomas, 2 hamartomas e casos isolados de adenoma, neurilemoma múltiplo e coristoma. As análises bivariadas indicaram associação entre malignidade e massa abdominal palpável $(P=0,003)$, tempo de sintomatologia prévio ao diagnóstico $(P=0,016)$, anemia $(P=0,020)$, anorexia $(P$ $=0,003)$, dor abdominal $(P=0,031)$, emagrecimento $(P=0,001)$, náuseas/vômitos $(P=0,094)$ e obstrução intestinal $(P=0,066) ;$ não foi encontrada qualquer associação com as características demográficas (sexo e idade) dos pacientes. No modelo final de regressão logística, emagrecimento, anemia e obstrução intestinal mostratam-se estatisticamente associados com a variável dependente de interesse. Levando-se em consideração somente três variáveis - emagrecimento, anemia e obstrução intestinal - foi possível predizer a malignidade de tumores jejuno-ilelais primários com sensibilidade de $85,2 \%$, especificidade de $80,0 \%$ e acurácia de $83,3 \%$.

DESCRITORES - Neoplasias do jejuno. Neoplasias do íleo. Fatores de risco.

\section{REFERENCES}

1. Arber N, Neugut AL, Weinstein IB, Holt P. Molecular genetics of small bowel cancer. Cancer Epidemiol Biomakers Prev 1997;6:745-8.

2. Ashley SW, Wells SA Jr. Tumors of the small intestine. Semin Oncol 1988;15:116-28.

3. Baigrie RJ. Seven different primary cancers in a single patient. A case report and review of multiple primary malignant neoplasia. Eur J Surg Oncol 119;17:81-3.

4. Calman KC. Why are small bowel tumours rare? An experimental model. Gut 1974; $15: 552-4$.

5. Chak A, Canto MI, Rösch T, Dittler HJ, Hawes RH, Tio TL, Lightdale CJ, Boyce HW, Scheiman J, Carpenter SL, Van Dam J, Kochman ML, Sivak MV Jr. Endosonographic differentiation of benign and malignant stromal cell tumors. Gastrointest Endosc 1997;45:468-73.

6. Kleinbaum DG. Logistic regression: a self-learning text. New York, SpringerVerlag, 1994.

7. Lowenfels AB. Why are small-bowel tumours so rare? Lancet 1973;1(7793):24-6.

8. Maglinte DD, O'Connor K, Bessete J, Chernish SM, Kelvin FM. The role of the physician in the late diagnosis of primary malignant tumors of the small intestine. Am J Gastroenterol 1991;86:304-8.
9. Miles RM, Crawford D, Duras S. The small bowel tumor problem: an assessment based on a 20-year experience with 116 cases. Ann Surg 1979;189:732-40.

10. Minardi AJ Jr, Zibari GB, Aultman DF, McMillan RW, McDonald JC. Smal-bowel tumors. J Am Coll Surg 1998;186:664-8.

11. Ostermiller W, Joergenson EJ, Weibel L. A clinical review of tumors of the small bowel. Am J Surg 1966;111:403-9.

12. SAS Institute Inc. SAS stat user's guide. Version 6. 4.ed. Cary, NC, 1989. v.1-2.

13. Serour F, Dona G, Birkenfeld S, Balassiano M, Krispin M. Primary neoplasms of the small bowel. J Surg Oncol 1992;49:29-34.

14. Taggart DP, Imrie CW. A new pattern of histologic predominance and distribution of malignant diseases of the small intestine. Surg Gynecol Obstet 1987;165:515-8.

15. Wang CC, Wu MS, Wang HH, Wang HP, Lee WC, Shun CT, Lin JT. Helicobacter pylori infection and age on the development of intestinal metaplasia: a multiple logistic regression analysis. Hepatogastroenterology 1998;45:2234-7.

16. Wyllie AH. Apoptosis and carcinogenesis. Eur J Cell Biol 1997;73:189-97. 